\title{
Exploration on the Construction of Basic Framework of Employment Service System in Colleges and Universities under the New Situation
}

\author{
Wang Xiaoling ${ }^{1,2, a}$ Jiao Fanghong ${ }^{3, b}$ \\ ${ }^{1}$ Baicheng Normal College,Student Employment Office,Baicheng,Jilin \\ ${ }^{2}$ Baicheng Normal College,College of Life Sciences,Baicheng,Jilin \\ ${ }^{3}$ Baicheng Normal College,Media College,Baicheng,Jilin \\ abcwxl@126.com; jijiaofanghong66@163.com
} Keywords: Colleges and universities; Employment service system; Basic framework; Construction;
Exploration

\begin{abstract}
With the popularization of higher education, the number of college graduates in China is on the rise, while the employment rate of university graduates has not increased, and the employment situation is not optimistic. Due to the influence of social factors, policy factors, geographical factors, family factors and so on, there are still some problems in the employment system of ordinary colleges and universities, so it is very important to explore the countermeasures to solve the problems and construct the employment system in colleges and universities under the new situation The After several years of practical exploration, the author clarifies the connotation, function and construction principle of the employment system of college graduates, puts forward the countermeasures to solve the problems, and explores the framework of constructing the public employment service system of ordinary college graduates.
\end{abstract}

\section{Introduction}

At present, the employment problem of college graduates at home and abroad is generally concerned. The employment service of university graduates involves many elements of colleges and universities, government and society. It is a systematic project, which is related to social stability. The employment problem of college graduates has always been influenced by the party And the state attaches great importance. It is of great theoretical and practical significance to strengthen the research on the employment service system and construction of college graduates.

The employment service system of college graduates is based on the students' specific service object, so as to create a good employment environment for college students, guarantee and improve the employment of graduates. It is characterized by multidimensional, multilevel and multifaceted, including the Ministry of Education, Schools and other specialized organizations in the country to develop a variety of specific laws and policies, as well as the relevant regulations, under the guidance of a series of specific services called the general term. It can be seen that the student is the main body of the college graduates service system, the service is the center of the college graduates service system. Therefore, we must emphasize the student-oriented, and establish the concept of serving the students wholeheartedly. Educate students to fully understand themselves, understand the community, to guide students to career planning, and enhance the ability of college students to career, and gradually achieve their career goals. Encourage students to work hard in hardship places to work at the grassroots level.

\section{The Function of College Graduates' Service System}

College graduates service system services object, one is college students, the other is the employer. To meet their wishes and requirements, to provide the necessary conditions. To provide students with policy interpretation, employment situation analysis, psychological counseling, systematic professional skills training, test skills counseling, job training, etc., for the employer to provide places, facilities and other services for the two to provide the necessary information to build two-way choice platform. 
It also carries on the instruction and evaluation of the career planning, outlook on life, values, world outlook, career view and employment view, and also carries on the historical responsibility of cultivating the excellent professional employment instructor.

To carry out all-round management of college employment. Linking the employment staff of the school with its work tasks to achieve the program objectives in the employment service system. The employment service system is a bridge between schools, employing units, social talent institutions and news media, and a platform for students and employers to build communication. Responsible for the construction and management of the employment guidance teachers in colleges and universities; expand the employment channels, develop and manage the employment market.

\section{Problems in the Employment Service in Colleges and Universities and the Countermeasures}

The guidance teachers need not only have rich theoretical knowledge, know the theory of employment and service at home and abroad, but also have strong practical ability and rich experience of employment guidance. But so far, our country does not have a specialized training of employment guidance and service of colleges and universities, therefore, the employment mentor team is a non-employment professional team, members of the level of uneven, the overall lack of systematic expertise and specialization Expert quality, poor level, the ability to have some limitations, is the prevalence of the phenomenon. The employment instructor may be composed of two parts of the part-time staff, in the school selection of some love, willing to sacrifice, have great enthusiasm, love employment guidance work and have a certain theoretical knowledge of teachers. Colleges and universities through various channels to improve the professional level of employment guidance teachers, through the "introduction to send out" approach to its systematic training to improve their employment guidance theory and practical ability. "Introduction" refers to the recruitment of social and other provincial level above the practical experience of senior scholars on the full-time employment guidance staff for theoretical guidance and skills training; "sent out" refers to the Ministry of Education, the Ministry of Education and other organizations of the employment of entrepreneurship education training, or let it communicate with the employer, so that it can understand the needs of the community to the talent, so that guidance targeted. Part-time teachers are composed of excellent entrepreneurs, professional instructors, highly respected social celebrities, they have a wealth of workplace experience, a strong workplace practice. Let them talk about the status quot of the workplace, employment market analysis, participation in the employment guidance course lectures. Only to create such a knowledge-rich skills excellent high-quality employment guidance teachers, the overall level of employment guidance work can be improved, the employment guidance effect will be significantly improved.

With the rapid development of society, the industrial structure is also changing, the community's demand for talent is also rising,Social needs of the people, first of all have a noble professional ethics, physical and mental health, but also a solid, with a certain breadth and depth of professional knowledge, but also to have the sense of innovation, communication and coordination, organization and many other aspects of the ability and excellent professional skills Excellent talent. Therefore, colleges and universities should be based on the need to optimize the school and social resources, adjust the training program, teaching, methods and methods to cultivate the model to innovate. Remove obsolete old knowledge, add useful knowledge, long life and new knowledge. The need for social needs as a fundamental point, set some social needs, popular, high employment rate of professional. The development of modern science and technology, social needs, to promote social progress and development of emerging disciplines. In the teaching and personnel training, the professional and general education combined with the organic combination of humanities and science education; the common sex and personality education combined. Training with a high overall quality and ability of practical talents. Improve the employ ability of students, so that it can be well adapted to the needs of the community.

The three elements involved in the employment guidance course are teachers, teaching materials and teaching contents. Professor of employment courses should be a team of teachers with noble moral integrity, excellent political quality, have access to national policy, timely update of 
educational ideas, integration of knowledge, communication and many other strong ability of a vibrant, Of the faculty. Choosing a good job guide is critical to job development. But some colleges and universities blindly follow the trend, did not take into account the actual school, casually booked the textbook, the results ineffective. Colleges and universities should be based on the nature of the school, students, geographical location and other carefully selected materials. If possible, it is advisable to organize excellent teachers to prepare school-based textbooks that meet the characteristics of our school. And the employment guidance course teaching content is essential to the student employment guidance, its teaching content should be full, rational, life, humanization. Its content should help the students to the correct outlook on life, values, world outlook, career choice, the establishment of employment concept. Help students understand the employment situation, employment policy; understand the new situation under the college graduates should have the quality and ability to help master the written and interview skills; help psychological debugging and ease, ease the employment pressure; help So that students use the law to safeguard their legitimate rights and interests; help students understand the employment procedures and ways, less detours, smooth employment; help students grow into talent; contribute to the optimal allocation of human resources.

China from 1996 to university graduates to the talent exchange market, although today has gone through 20 Spring and Autumn, due to lack of experience, employment policy is not sound is inevitable. In order to meet the growing needs of employment services, to mobilize all aspects of power for college graduates employment services. Perfect the employment policy of college graduates, create a good employment environment, do a good job in employment services.According to the employment situation, timely reform of college students to cultivate the means to set up a reasonable general education and professional courses, pay attention to the overall quality of students training and improvement. Establish a stable and practical practice base, enhance skills training, improve student skills. Encourage students to get a diploma at the same time, we must strive to obtain vocational qualification certificate, so that students can master a variety of skills, so that the employment channels to be broadened to improve the employ ability of students and enhance student social adaptability.In accordance with the requirements of the Ministry of Education, colleges and universities should be the vocational guidance of students into the education curriculum teaching plan, all students in the whole process, all-round and comprehensive guidance, through the development of policies, clear employment guidance in college students training process The role of the university and the basic unit of teaching in the employment guidance of college students in the duties. Through the guidance of policy support to ensure the smooth progress of vocational guidance work for college students. Through the social employment service agencies, or enterprises and institutions to provide trainee positions, the school with its relevant institutions, departments to carry out training and trainees to improve the employ ability of college graduates to achieve their role in life conversion. "Kong Kong internship" is a very good way. During the internship period, the relevant government departments should jointly formulate the relevant preferential policies for the subsistence allowance and related insurance protection and follow-up. The relevant policies should be formulated in terms of teaching and examination.

\section{The Principle of Constructing the Service System of College Graduates}

Scientific principles: employment guidance work is a comprehensive and strong educational activities, must follow the law of education. Employment is affected by social economy, politics, system and culture, and serves social and economic, political and cultural development. At the same time, it is necessary to carry out education according to the age characteristics of the students and promote the physical and mental development of students. Materialism argues that these laws are inherent in education itself and are not transferred by human will.

Holistic principle: the system is the organic unity of the elements, the system as a whole, its nature and function is not the existence of each element when the nature and function of a simple sum, nor can the overall nature and function simply reduced to the nature of the elements and Features. The cultivation of talents in colleges and universities is an organic whole. Graduates' 
employment is part of this organic whole. The relationship between the elements within the employment service system is interrelated, mutually supportive and mutually restrictive. Therefore, the establishment and improvement of the employment system of college graduates must adhere to the principle of integrity, each component is placed in the organic whole of personnel training, and other parts of the link to understand. On the one hand, it is necessary to coordinate the relationship between the subsystem and the large system. On the other hand, it is necessary to coordinate the relationship between the subsystem and the subsystem so that the various elements of the system can work together and make the overall function of the system greater than The simple addition of each subsystem function.

People - oriented principle: the main body of college graduates service system is the students, no students how to talk about college graduates service system. College employment service system in all the elements, all activities point to the goal is the students. Therefore, colleges and universities to build and improve the employment service system, we must start from the needs of students, students want to think, the urgency of urgency, according to the needs of the country, students need to update their ideas, build a new model of personnel training, , Adjust and optimize the professional courses, reform teaching content, methods, means to reform the quality of education evaluation mechanism and the development of personnel evaluation standards, to build a new employment service system.

Feasibility principle: the use of existing resources, the selected factors are simple, to meet the service functions, the elements of the building easy to operate. In short, the construction of the service system should be oriented to the correct, comprehensive and reasonable, easy, so as to achieve the purpose of service.

The principle of fairness: the employment system of graduates should break through all restrictions and open to all graduates of the school. The service object should include the master's degree, the undergraduates, the junior college students, regardless of the sex, the nationality, regardless of the family economic condition, whether the place of residence is the city or the village.

\section{The Basic Framework of the Service System for College Graduates}

Organizational policy system:Organizational policy system, including policy guidance services and work organization services two sub-system, the entire college graduates employment service system under the implementation and specific implementation are carried out under its command. The key to doing a good job of graduating services is the leadership of a high degree of attention, well-organized, division of labor. Leaders at all levels attach importance to the progressive implementation of the responsibility, the implementation of "number one" project. The establishment of college graduates meeting system and job transfer mechanism, so that the normal employment service system graduates to be guaranteed.

Employment Guidance System:The employment guidance system includes two sub-systems of employment guidance service and employment guidance team. The whole employment service system refers to the employment service of all students from all aspects of schooling until graduation. Construction of faculty with guidance on content related to employment. With the popularization of higher education in China and the deepening of the socialist market economy, the employment guidance of college students has gradually become a systematic project. Starting from freshman freshmen, the cultivation of employment consciousness and employment guidance Education and teaching the whole process, students in every aspect of career planning, every link, each stage has the appropriate institutions and part-time staff to provide guidance services, and employers in the recruiting college graduates, you can get the university The authoritative college graduates of various information services. 


\section{Conclusion}

The employment system is related to how to carry out the employment work; support the security system is the whole system of solid and continuous operation of the fundamental guarantee. The ultimate goal is for all graduates employment services, in order to graduate employment all services, all services for graduates employment.

\section{Acknowledgments}

This work was supported by the "Research on the Construction of Public Employment Service System for Graduates of Ordinary Colleges and Universities in Jilin Province” (Jilin Provincial Department of Education 12th Five - Year Social Science Research Project, No. 386, 2015) in part. The author would also like to thank the reviewers for their corrections and helpful suggestion.

\section{References}

[1]Ye Yingrui.Green Management Concept under the Guidance of the New Path of Employment Management in Colleges and Universities [J].Management of the World, 2015(03).

[2]Wang Xiaoling. Construction of Ordinary College Graduates Public Employment Service System Path [J].Journal of Baicheng Normal College,2016(11).

[3]Gu Zhengjie. The Improvement of the Training Methods of the Employment Guidance Teachers in Colleges and Universities [J]. Journal of Sichuan Polytechnic University, 2013(06).

[4]Feng Ling,Li Fuwei.The Strategies and Methods of Innovating the Employment Management in Colleges and Universities under the New Normal State [J].Journal of Higher Education and Social Education,2015(08).

[5]Ye Lingfen.Analysis on the Current Situation and Countermeasures of the Employment Ability of College Graduates [J].China's Outside Education,2014(03).

[6]Zhu Jin, Wang Zhibing.Research on the Influence of Knowledge Spillover on College Students' Entrepreneurship [J].China's Outside Education,2014(04). 